russian-english references glossary Mass media and telecommunications. Редактор-құраст.: Қ. Тұрсын-Aлматы, «Қазақэнииклопедиясы» басnасы, 2015. - 632 б.

17 Қалиұлы Б. Қазақұиа термин жасау мәселесіжәне оны құалыптастырудавы БАҚ-тың рөлі. Қазақ терминологиясы және Бұқ̧аралық ақппарат құралдары // Республикалық выльлми-практикальқ конференция материалдары. - Астана, 2013, 128 б.

\title{
References:
}

1 Amırov A. Kazak baspasozının 1990-2000 jyldar aralygynda terminologia Kalyptastyrudagy roll. // filol.gyl.kand. gylymi dArejesin alu usin daiyndalgan disertasia. - Almaty, 2002. 116 b.

2 Ahmanova O. SlovAr lingvisticheskih terminov. - M.: Sov.ensiklopedia, 1966.C. 607.- ensiklopedia

3 Prohorova V. AktuAlnye problemy sovremennoi ruskoi leksikologii. - M.: Izdatelstvo MGU, 1973. C. 401.

4 Usakov D. Tolkovyi slovAr ruskogo iazyka. - M.: Astrel, 2000. T.IU-752. C. 689.

5 Superanskaia A., Podolskaia N., Vasileva N. Obsaia terminologia //Voprosy teori.-M.: Nauka, 1989. C. 243

6 Jubanov K. Kazak tıl jonindegl zertteuler. - Almaty:Gylym, 1966. -362 b.

7 Kaliuly B. Kazaksa termin jasau mAselesı / TerminologialyK habarsy, 2014, №1 (49), 12-17 b.

8 Kurmanbaiuly S. TerminKor Kalyptastyru kozderl men terminjasam tAsılderl. - Almaty:»Sozdik-SlovAr», 2005. $-240 \mathrm{~b}$.

9 Masgutov S. Koglldır ekran - omır ainasy. - Almaty: Mektep, 1976. - 131 b.

10 Barmankulov M. Televidenie: dengi ili vlAst? - Almaty: Sanat, 1997. - s. 268.

11 Tursyn K. Kazak telejurnalistikas: Kalyptasu, damu problemalary. - 2-basylym. - Almaty: Kazak universitetı, 2013. -356 b.

12 Masgutov S. TelevizialyK jurnalistika negıderıne kırlspe. - Almaty, 1975 . - 110 b. -kıtap 36.

13 Volhonski V. Problemy terminologii televizionnyh sistem nabludenia /Algoritm bezopasnosti, 2006, №1, s.34-

14 Tursyn K., NusKabaiuly J. Teledidar sozdigl - telejurnalist anyKtamalygy: OKu Kuraly. - Almaty: «Bılım», 2001. $-380 \mathrm{~b}$.

15 Novikova E. G., Petrakov A. V., Rabovski S. V. Biznes - Bezopasnost-Telekommunikasii. Terminologicheski slovAr. M.: Radio i svAz, 2001. - C. 304.

16 Malisevski E. O nekotoryh problemah terminologii v sifrovom televizionnom vesanii /Informasionnye telekommunikasionnye seti, 2019, №9, s. 32-33.

17 Mass media jAne telekommunikasia terminderının Kazaksa-oryssa-agylsynsa anyKtamalyK sozdıgl. Kazahskorusko-angliski spravochnyi slovAr terminov Massmedia i telekomuniksi. Kazakh-russian-english references glossary Mass media and telecommunications. Redaktor-Kurast.: K. Tursyn - Almaty, «Kazakensiklopediasy» baspasy, 2015. $632 \mathrm{~b}$.

18 Kaliuly B. Kazaksa termin jasau mAselesijAne ony Kalyptastyrudagy BAK-tyn rolı. Kazak terminologiasy jAne BuKaralyK aKparat Kuraldary // RespublikalyK gylymi-praktikalyK konferensia materialdary. - Astana, 2013,128 b.

МРНТИ 19.21.07

https://doi.org/10.51889/2021-1.1728-7804.69

Ospanova U., ${ }^{1}$ Shakenova $M .^{2}$

1, 2 JSC “Information and Analytical Center” under the MES RK,

Nur-Sultan, Kazakhstan

\section{MEDIA IMPACT TYPOLOGY IN SCIENTIFIC DISCOURSE}

This article provides a theoretical overview of existing research with particular focus on the types and models of media impact on the individual and society. The analysis of scientific literature has revealed that despite popularity and extensity of exploration of the issue in the scientific discourse some major inconsistencies are still observed. It should be noted that in most cases the studies are fragmentary, the influence of the media on various social groups is mostly considered from one specific position, and the lack of clearly developed criteria for the typology of media impact. Summarizing the accumulated knowledge in this area, we tried, despite the complexity of identifying and systematizing the classification of media impact, to present a complex typology of media influence on the individual and society.

Keywords: media influence, typology, mass media, influence on society

Оспанова У.А., ${ }^{1}$ Шакенова М.T. ${ }^{2}$

${ }^{1,2}$ ҚР БҒМ жанындавы “Ақุпараттық-талдау орталывы” ” АК,

Нұр-Сұлтан, Қазақстан 


\title{
ҒЫЛЫМИ МӘТІНДЕ БҰҚАРАЛЫҚ АҚПАРАТ ҚҰРАЛДАРЫНЫҢ ӘЛЕУМЕТКЕ ӘСЕРІН ТУРГЕ БӨЛУ
}

\begin{abstract}
Аңудатпа
Макалада бұқаралық ақпарат құралдарының тұлғаға және әлеуметке әсері нің түрлері мен модельдері жайлы жүргізілген зерттеулерге теориялық шолу жасалған. Ғылыми әдебиеттерге жасалған талдау бұл мәселенің ғылыми зерттеулер мәтінініде танымал және жеткілікті түрде екшелген екенін анықтап берді. Бірақ, айта кету керек, көбінше зерттеу жұмыстары фрагменттер ретінде ғана жүргізіліп келген, БАҚ тың әртүрлі әлеуметтік топтарға әсері белглі бір көзқарас көлемінде ғана қарастырылғандықтан, бұқаралық ақпарат құралдарының әлеуметке әсерін түрге бөлудің нақты дайындалған критерийлері болмады. Осыған байланысты осы мәселе төңірегінде жинақталған білімді қорытындылай келе, әртүрлі әлеуметтік топ мүшелеріне тигізілген әсерердің түрлерін жүйелеу оңай болмаса да, бұқаралық ақпарат құралдарының жеке тұлғалар мен жалпы әлеуметке әсерінің кешенді топтастыруын ұсынып отырмыз.
\end{abstract}

Түйін сөздер: бұқаралық ақпарат құралдарының әсері, типологизациялау, БАҚ, әлеуметке әсері

\author{
Оспанова У.А., \\ ${ }^{1,2}$ АО “Информационно-аналитический центр” " при МОН РК, \\ Нур-Султан, Казахстан
}

\section{ТИПОЛОГИЗАЦИЯ МЕДИАВОЗДЕЙСТВИЯ НА СОЦИУМ В НАУЧНОМ ДИСКУРСЕ}

\begin{abstract}
Аннотация
В настоящей статье представлен теоретический обзор существующих исследований о видах и моделях медиавоздействия на личность и социум. Анализ научной литературы выявил, что в научном дискурсе данный вопрос является весьма популярным и достаточно разработанным. Однако, следует отметить, что в большинстве случаев исследования носят фрагментарный характер, влияние СМИ на различные социальные группы рассматривалось с одной определенной позиции и что отсутствуют четко выработанные критерии типологизации медиавоздействия на социум. В связи с этим, обобщая накопленные знания в данной области по указанной проблематике, мы попытались, несмотря на сложность выделения и систематизации типов влияния СМИ на личность и общество, представить комплексную типологию медиавоздействия на индивидуума и социум.
\end{abstract}

Ключевые слова: медиавоздействие, типологизация, СМИ, влияние на социум

Introduction. The influence of the media has been considered in the scientific literature from various perspectives. Recently, the generally accepted history of scientific research in media influence has been reviewed by a number of researchers, but still lacks the systematization.

According to W. Severin and J. Tankard, the traditional version of the process of evolution in the field of media influence research assumes the existence of several periods [1]. The dominant paradigm of the first period, which began approximately after World War I, is the view that the media have a powerful impact on the beliefs, views, and actions of the audience, in the framework of the "bullet theory." This model considered the individual as a passive element that accepts information transmitted by the media, perceives it, and acts in accordance with the broadcast message. The most famous work of this period was G. Lasswell's "Methods of propaganda in the World War," which considered various propaganda methods based on content analysis of propaganda materials of World War I [2]. In the early 40s of the twentieth century, the second period began, during which the paradigm shifted towards beliefs about the media's limited influence. Empirical studies by P. Lazarsfeld [3] and K. Hovland [4] have shown that the media have only a limited impact on individual audience members. The most influential work of this period is J. Clapper's study "effects of mass communication," conducted in 1960, which emphasized that the type and degree of media influence on an individual depend not only on the editorial policy and content of the media text but also to an eKual or even greater extent on the individual himself, his/her mindset, attitudes, readiness and desire to perceive such information [5]. The next two paradigm shifts in the next two periods, when the model of limited media influence was replaced first by models of a moderate impact and then by models of strong (significant) impact, occurred due to the need to revise the approach to periodization in the light of the appearance of new works and identify shortcomings of the old paradigm. The new paradigms recognized the diversity of the intensity of media influence on society as a whole and on the individual, in particular, in the range from limited to strong, sometimes to very significant.

Currently, the scientific community recognizes that the media have a significant impact on society and individuals being considered the "fourth power", but finally, the degree of influence depends on many factors and is a two-way process of information transmission from a broadcaster to a recipient, where the importance of the effect has the characteristics of the translator (posture, gestures, appearance, gender, race, information channel, and its reputation), the contents of the transmitted messages, a method of transmitting messages (tone, choice of words, intonation), 
characteristics of the recipient (gender, age, knowledge, values, internal settings, psychological characteristics, previous experience) and environment etc.

In general, despite the popularity and degree of development of media influence on society, research is fragmented, and Kuestions about the system and/or hierarchical structure of the types and results of media influence remain open. Also, J. Bryant and S. Thompson note the need to review certain points in the history of scientific research in the field of media influence and recognize the contribution of less well-known works. The authors note the lack of standard empirical criteria that allow classifying the impact of mass media by the degree of intensity of impact, the ambiguity of circumstances and conditions that explain the features of influence at different levels, as well as cause various forms of media influence. In addition, a number of authors note the lack of a unified concept and methodology, the ability to cover all aspects of the complex phenomenon of media influence [6].

Research in media influence (media impact, media effects, media impact) is extremely numerous. Still, last attempts to generalize and systematize the results of such research were made in the 60-80s of the twentieth century. Though there are well-developed models of media influence on society and individual social groups at the present stage, as a rule, most studies do not consider groups in comparison. Furthermore, to our knowledge, despite the comprehensive theoretical and practical justification of individual media impacts types and effects, there are no up-todate attempts to synthesize the typology. In view of the above, the main goal of the article is to build up the typology of the media impact and systematize the accumulated knowledge regarding media impact types.

The main body of the article includes the sections as follows: a) brief description of methods and research design logic; b) review results including the sub-sections; c) discussions; and d) conclusion.

Methods. In the view of the main goal set, the objectives determined for this review article are as follows: a) propose a comprehensive typology of media influence; b) systematize the findings of existing scientific papers in the view of the typology proposed; c) pay tribute to most prominent scientific works in the subject area.

The basic research method is a mixed methods review which in its essence generally relies on systematic literature review related to the subject area including comprehensive searching and typological analysis aimed at descriptive Kualitative analysis according to the selected criterion resulting in the development of a set of related categories within the mass media impact. To summarize, the research design logic implies such stages as a) extensive review of scientific literature related to media impact; b) determining typology criteria based on the empirical evidence obtained from previous stage; c) description of typology based on the literature review with justification of the typology by brief description of the selected works in line with it; d) systematization of media impact types according to the criteria determined and comments on observations.

Results. The first criterion of media impact typology is the coverage. This implies to at least 2 categories broadly covered by media impact related research papers: a) impact on an individual; b) impact at the level of social groups and society.

Models and research on individual media influence look at the impact in terms of the effect on a particular individual. In almost all such studies, the individual impact of the media on a person is considered not only from the point of view of coverage (individual - social group - society) but, like many other studies in the field of media interaction, several aspects of influence are considered simultaneously in the aggregate. Thus, the model by G. Comstock and co-authors, focusing on individual media influence, simultaneously takes into account such aspects of media influence typology as an influence on behavior, direct impact, and cognitive impact [7]. The Comstock Model shows how the process of learning and adopting behavior patterns broadcast by the media takes place. Although the model investigated the influence of television broadcasts, its postulates can also be transferred to the description of the influence of Internet news media. By reading analytical articles, an individual can learn how to interpret and analyze information and adopt the author's point of view. According to this model, the results of influence and adoption of behavioral patterns are determined by individual characteristics of a person, the psychological significance of the message, and the degree of excitement ("agitation") the individual achieved as a result of using such behavioral patterns. In this model, the intensity of influence depends on how real the broadcast media images seem to the individual: the more realistic, the stronger the psychological impact on the viewer and their behavior.

Along with the model by G. Comstock, the model of individual influence recognized by the scientific community is the Thorson model of cognitive processing [8]. Just like the previous model, in addition to individual impact, this model simultaneously considers other aspects of the typology of media influence, for example, its cognitive aspect. In addition to the factors considered by other authors, the Thorson model considers the viewer's interest, the level of memory development, and language abilities when describing the factors and stages of processing information transmitted by the media. Like the previous one, this model focuses on the influence of visual information (TV commercials). Still, processing and taking into account the individual characteristics of the individual perception of information is also applicable to news texts.

According to Sandra Ball-Rokeach and Melvin Defleur, there are many ways in which people become dependent on the media to meet the needs of obtaining information. There are several forms of dependence, of which the first is due to the desire to understand your own social world; the second is based on the need for meaningful and effective activity in this social world; the third- the form of dependence is associated with the need to release from stress, everyday life, and vanity. It should be noted that if the need and dependence are very strong, then the probability of the influence of information received from the media on public perception, feelings, and behavior increases significantly [9]. 
Theoretical models that consider the influence of the media at the social level are extremely numerous. So, one of the famous models by Sandra Ball-Rokeach and Melvin Defleur, examining the relationship between media and society, involves the continuous growing dependence of society from the media, acting as the main sources of information, including news, and the level of such dependence and the intensity of the impact is related to the stability of society and social value media. This model emphasizes the increasing role of the media and their influence in critical situations or in cases where the audience does not have information about the situation (for example, the audience is not a direct participant in events or does not have access to documentation), and the media becomes the only channel for obtaining such information. In this model, the media can become a source of information and a means to obtain psychological comfort. The dependence of society on news information is due to the social nature of a person, his/her belonging to a particular category of society, as well as certain individual needs. Also, the uniKue information functions of the media system affect people's dependence on the information. It should be noted that the information load of the media varies; some of them have a higher social significance. In other words, not all media are very important for society's well-being and the individual in particular.

Functions depend on time circumstances, situations, and units of analysis. For example, for politically active population groups, the functional load of information about national sports is likely to be significantly lower than that of information about the national economy or politics. Conversely, the opposite effect is possible for a politically passive population [9].

Also, a number of works consider the types of media impact in terms of its intensity. The influence can be divided into a) zero; b) limited; c) moderate; d) strong.

Although this differentiation is common in research, there are no generally accepted empirical criteria for determining specific parameters according to which influence can be classified as zero, limited, moderate, or strong. Thus, a significant number of authors rely on statistical parameters (for example, statistical significance). For example, to differentiate the influence, W. J. McGuire calculated the percentage of variations caused by various dependent variables of the media effect [10]. Also, a number of researchers in the course of surveys rely on the individual assessment of research participants, who in the framework of the study on the degree of intensity of the influence of certain materials, choose the degree of intensity from the proposed options, ranked on the Likert scale in accordance with their own opinion. Uniform intensity criteria, therefore, remain an issue that reKuires further clarification.

In addition, J. Bryant and S. Thompson note that "an obvious lacuna in the scientific literature on media impact is the absence of a 'zero-impact model'. These authors claim that, except for the study by F. Mott [11], scientists do not pay enough attention to the analysis of variables or cases of lack of media influence, calling zero impact as "the missing piece of the puzzle" [12]. indirect.

Analysis of the scientific literature also revealed another common typology of a media impact: a) direct; b)

However, the criteria for attribution to one of the classes of this typology also remain insufficiently developed. In general, there are two different lines of interpretation of the terms "direct - indirect influence" in the scientific literature. A striking example of the work of the authors of the first line of interpretation is the study of K. Seymour-Ur [13], who gives the most illustrative analogs of the term "direct influence" - "primary influence" and the term "indirect influence" - "secondary influence." Here, the media's primary influence is shown in cases where the individual directly participated in the communication process. And the secondary (indirect) influence of the media is shown in cases where individuals or groups of individuals subjected to primary influence impact those who were not subjected to primary influence. Thus, according to this typology, indirect influence is a conseKuence of direct influence on individuals exposed to the media. Within this line of interpretation of the terms "direct - indirect influence," which is supported by a number of authors, an important role is played by agents involved in the communication process. These are the socalled "opinion leaders" who broadcast their own interpretation of media materials to the part of the audience that is either not familiar with the materials themselves or is only superficially familiar. Typology criteria are objects of influence or agents through which influence occurs.

In another line of interpretation of the terms "direct - indirect influence," the criterion for determining class affiliation is not the object, but the way information is presented. So, those media materials that directly describe the pattern of behavior and activity are considered to have a direct impact, and texts or materials that have an indirect impact using psychological techniKues and cognitive features of the brain (for example, broadcasting the image of a successful person in advertising videos) often have an unconscious influence, defined as indirect [14]. This line of interpretation is often supported by authors who consider the psychological effects of media influence.

Within the first line of interpretation, H. Kepplinger distinguishes three types of indirect influence [15]. An example of the first type, called by the author as "administrative reaction," can serve as a change in a group of decision-makers' behavior under the influence of the reaction of large social categories that were directly influenced by news information. The second type of "impact on society" occurs in the opposite direction, when decision-makers under the influence of news media information change their behavior in a certain way, which in turn affects broad social categories or society as a whole. The third type is the "snowball effect" when large groups of recipients of information presented in the media indirectly impact large social categories that were not initially affected by such media information. 
Types of media influence by the duration of influence include short-term, medium-term and long-term impacts. In this case, as in the case of typology depending on the intensity, precise empirical criteria for the boundaries between classes are not defined.

Before proceeding to description of the next typology criterion, it is noteworthy to mention some fundamental theories that underpinned it. First of all this refers to the theory of cognitive dissonance, proposed by L. Festinger in 1957, that gave impetus to other media effect theories and also initiated a number of concepts within the theory of selective exposure to media influence. According to L. Festinger, cognitive dissonance occurs as a result of the conflict of cognitive elements of consciousness that contradict each other [16]. An example is the inconsistency of beliefs and actions, knowledge, and behavior. According to L. Festinger, a person strives for cognitive balance, i.e., seeks to reduce or eliminate dissonance in two ways: 1) reducing the significance or number of dissonant elements; 2) changing dissonant elements to achieve consistency. In cases of dissonance between knowledge about the environment (for example, the individual's attitudes and knowledge about the norms of behavior in society) and behavior, its elimination is either by changing the behavior so that it comes into harmony with the environment or by changing the knowledge about the environment itself. In cases where the elimination of dissonance is not possible, individuals tend to reduce it. To illustrate, here is an example of a person with a cognitive dissonance between knowing about the dangers of fatty foods and being unable to give up eating habits. This person seeks to eliminate dissonance by adding new cognitive elements, for example, by reading materials that refute the harm of fatty foods.

This theory formed the basis of one of the largest theoretical trends in the scientific literature on selective exposure to media impact (selective exposure hypothesis). In this direction, it is argued that the desire for cognitive balance is the reason why individuals are more affected by certain types of media content and play an important role in the individual's media preferences. Thus, the audience's selectivity shows when choosing materials in the media to read, as well as when making decisions based on the material read in the media, including changes in their own behavior, depends on many personal factors that form their cognitive field. One of the assumptions made within the framework of selective exposure to media influence, which has been confirmed in scientific research, is the desire to avoid reading/ignoring materials that contradict existing cognitive attitudes. In the study by $\mathrm{J}$. T. Klapper, it is noted that in order to preserve the integrity of their own system of knowledge and beliefs, readers prefer those media materials that are consistent with their own attitudes formed earlier (selective exposure to influence), interpret media materials in accordance with such attitudes (selective perception) and remember such materials longer than those that are not consistent with their attitudes (selective memory) [5].

Another model developed within the theory of cognitive dissonance, and the paradigm of selective exposure to influence is the SESAM (Selective Exposure for Self and Affect-Management) model. It assumes that media users choose materials in such a way as to adjust their perceptions of their own personality in accordance with affective and cognitive states and behavioral patterns. Exposure to and reaction to media materials, in turn, have an impact on individual self-determination, which is a dynamic and interdependent process. Thus, a person's gender can be considered as one of the elements of self-determination, which reKuires compliance with gender norms of behavior. Media materials represent a social context that confirms or refutes various elements of self-determination of the individual. In turn, the latter determines the individual's choice of materials to read and the degree and type of influence of materials on personal development and behavior. The SESAM model postulates were used in separate studies to determine selective exposure to media materials related to concepts such as gender, race, politics, and health [17].

The following typology criterion - type of affected aspect - is most extensively covered by the academia. We believe that, W. J. Potter's classification of media impact typology as physiological, cognitive, influence on beliefs, influence on attitudes, influence on emotions (affective), and influence on behavior to be one of the most relevant [18].

The physiological impact of the media on the individual is associated with the so-called state of excitement. It is due to the peculiarities of the human brain and neuropsychological processes. The message transmitted by the media is processed by the brain, causing physiological effects such as skin reactions (redness, pallor, etc.), sexual arousal, failure of the spatial orientation reflex, agitation, etc. In connection with the physiological impact of the media on the individual, the habituation effect is often mentioned, when due to regular or freKuent exposure to the same type of media messages, the intensity of their influence on the individual gradually decreases, and in some cases disappears completely [19]. The strongest impact in physiological terms has a TV; print media's impact from the point of view of physiology has limited effects.

The media's cognitive impact is related to the process of assimilation and processing of information by the brain, the learning process, cognitive and thought processes. Media messages trigger various cognitive and thought processes, which are then transformed into knowledge. In the cognitive influence of the media, the individual's knowledge of the world around them also changes. Changes in the previous system of human knowledge occur over time as new facts are learned, social norms and phenomena that occur in the world are understood, and they are integrated with the existing system of knowledge (frames). Such authors have studied the influence of mass media on cognitive processes as D. Scheufele [20], who developed the "theory of learning," and R. M. Entman [21], who described the process of drawing conclusions based on information received by the reader (viewer) from fragmentary information and frames. R. Nickerson supplemented the description of the cognitive process by studying the processes of frame verification and reinforcement [22]. K. Braun LaTour also studied the processes of consolidating the existing knowledge system and M. LaTour [23], while the consolidation of thought processes were studied by Langer and A. Piper [24]. Researchers S. 
Ball-Rokeach and M. Defleur [9] note that most people receive information about unexpected and sudden events (for example, natural disasters, the death of political leaders) from various media channels.

The cognitive effect is also related to the role of the media in developing the agenda, that is, the choice of a certain range of topics and issues of interest to the audience. In other words, the selection of media outlets that sort potential topics of broadcast information is mostly not controlled. The media transmit information covering a wide range of topics. But, as a fact, the recipient of information often does not have enough time and energy resources to process all the information and form an attitude to it. In other words, the agenda is formed in the process of interaction. There is a filter of information through the system of collecting and processing information in the media, and then its selective distribution.

The impact of media on individuals' beliefs is often considered part of the influence on cognitive processes since the process of influence involves the construction of concepts and interpretations and is associated with memory. However, despite the obvious relationship, there are a number of aspects that allow us to distinguish the impact on beliefs and beliefs from the impact on cognitive processes. If the construction of concepts at the level of knowledge (the cognitive element) is based more often on facts, then beliefs and beliefs are more abstract and often do not reKuire confirmation by facts. According to A. H. Eagly and S. Chaiken [25], beliefs are recognized by an individual as true or false by analyzing objective external criteria. In some cases, the individual's beliefs are formed immediately after reading/viewing the media message.

The impact of the media on attitudes. W. J. Potter notes that even though many authors consider beliefs and relationships synonymous and their obvious relationship, these concepts still need to be distinguished [18]. The key difference between these two concepts is that the basis of a person's attitude to something is not the plausibility of how much the knowledge received by the individual corresponds to reality (as in the case of a belief), but a value judgment. As well as research on the influence of the media on beliefs, research on the influence of the media on attitudes examines the processes of formation, change, adoption, and consolidation of attitudes to certain objects and phenomena. However, many studies consider the influence of the media on relationships as part of or analogous to the media's influence on beliefs.

The impact of media on emotions. The impact of the media on people's emotions and feelings can take many forms. One of them may be learning and acKuiring emotions. For example, an individual can get information about what they can/should feel from video or text media materials. An example is Goleman's work, "teaching proper emotional responses, " published in 1995 [26]. The second most freKuently encountered and studied form of media influence on emotions is emotional arousal. Researchers working on this topic looked at what emotional reactions media materials cause in the audience, as well as the mechanisms and processes that lead to certain types of emotional responses. Analysis of such studies has shown that the bulk of the research consists of 3 large groups: studies on emotional arousal [27]; studies on generalized categories of emotions (negative/positive) [28]; studies that consider specific emotions (fear, anger, hostility, empathy, pride, etc.) [29].

The impact of the media on behavior. After reading media materials, people can learn new behavioral features, "launch" already formed behavioral attitudes (start behaving and acting in a certain way), change their own behavioral features, or consolidate existing patterns (form habits). Media influence on behavior is one of the most methodologically complex types of impact to study. This is primarily due to the need to distinguish between the concepts of "intent to change behavior" and "actual behavior change." The difficulty is also that an individual can temporarily change behavior under media materials' influence and then return to previously established habits. Tracking such fluctuations in behavior reKuires long-term observation of the study objects, which is not always possible. It should also be noted that this type of influence is closely related to other types of media influence, such as cognitive influence and influence on beliefs and emotions. Among the studies on the impact of media on behavior, it is possible to highlight the work of D. Tewkesbury [30], studied the effect of e-news about public policy on behavior. Some studies look at changing people's behavior under the media's influence positively, contributing to positive changes in society and the life of an individual. These include research by K. Harrison and co-authors [31], studying habit acKuisition and behavior changes towards a healthy lifestyle.

The typological analysis results are shown in Table 1 below.

Table 1 - Media impact typological analysis

\begin{tabular}{|c|c|c|}
\hline Criteria & Media impact typology categories & $\begin{array}{c}\text { Availability of } \\
\text { established/universal empirical } \\
\text { classification criteria }\end{array}$ \\
\hline \multirow[t]{2}{*}{ Coverage } & impact on the individual & Yes \\
\hline & impact at the level of social groups and society & Yes \\
\hline \multirow[t]{4}{*}{ Intensity } & zero & No \\
\hline & limited & No \\
\hline & moderate & No \\
\hline & strong & No \\
\hline
\end{tabular}


ВЕСТНИК КазНПУ им. Абая, серия «Филология», №1(75), 2021 г.

\begin{tabular}{|l|l|l|}
\hline \multirow{3}{*}{$\begin{array}{l}\text { Impact chain/Information } \\
\text { presentation }\end{array}$} & direct & No \\
\cline { 2 - 3 } & indirect & No \\
\hline Duration of influence & short-term & Partially \\
\cline { 2 - 3 } & medium-term & No \\
\cline { 2 - 3 } & long-term & Partially \\
\hline \multirow{5}{*}{ Type of affected aspect } & physiological & No \\
\cline { 2 - 3 } & cognitive & No \\
\cline { 2 - 3 } & impact on beliefs & No \\
\cline { 2 - 3 } & impact on attitudes & No \\
\cline { 2 - 3 } & affective (on emotions) & No \\
\cline { 2 - 3 } & impact on behavior & No \\
\hline
\end{tabular}

Discussions. The limitations of the research include bias occurring when selecting the typology criteria relying on personal experience of the authors, the bias related to the sampling of literature reviewed based on which the systematization of typology criteria was conducted.

The main finding of the research is the lack of established commonly accepted empirical criteria for classification according to the typology, in other words, the lack of understanding the exact measurements or Kualitative criteria based on which media impact can be attributed to a certain type. To illustrate, there is no clear understanding how exactly intense the observed media impact should be to assume it belongs to the "strong" class, or what the exact grounds to argue that the observed media impact was made on behavior but not on attitude are.

Another finding is the lack of coverage of certain typology classes in scientific literature. For example there is almost no research related to zero-intensity media impact in scientific discourse.

Also in case of the research on the impact on behavior, there is a little clear evidence and methodology on the actual change in behavior affected by media, particularly with regard to the difference between actual change in behavior and reported change in behavior resulting from the media impact. SubseKuently, in the view of the lack of clearness the attribution to the media impact type is highly Kuestionable.

Conclusions. In general, the described types of media impacts are interrelated. This is especially true for news media materials since familiarization with any news material involves the cognitive aspect of influence and influence on emotions, beliefs, and attitudes (often in an unconscious form). Changing an individual's behavior under the influence of the media is also impossible without the previous three aspects and often reKuires more time. The same refers to other types of media impact.

The typology proposed in this article is based on extensive literature review on media impact (effects) and can be considered Kuite comprehensive. The future research areas still reserve a substantial room for established empirical classification criteria between the media impact types systematized thereof.

This article was prepared as part of the implementation of the PTF \# BR05236839 on the topic "Development of information technologies and systems to stimulate sustainable development of the individual as one of the foundations of the development of digital Kazakhstan".

\section{References:}

1 Severin W.J., and Tankard Jr. J.W. Communication theories: Origins, methods, and uses in the mass media (3rd ed.). - New York: Longman, 1992

2 Lasswell H.D. Propaganda techniKue in the World War. - New York: Knopf., 1927.

3 Lazarseld P.F. Communication research and the social psychologist. In W.Dennis (ed.) // Current Trends in Social Psychology. - University of Pittsburgh Press, 1948. - P. 218-273.

4 Hovland C.I. Effects of the mass media on communication. In G. Lindzey (Ed.) // Handbook of social psychology. - Cambridge, MA: Addison-Wesley, 1954. - Vol. 2. - P. 1062-1103.

5 Klapper J. T. The effects of mass communication. - New York: The Free Press, 1960. - P. 302. - book

6 Bryant J., Tompson S., Finklea B.W. Fundamentals of Media Effects. - Waveland Press, 2012. - P. 410. - book

7 Comstock G., Chaffee S., Katzman N., McCombs M. \& Roberts D. Television and human behavior. - New York: Columbia University Press, 1978.

8 Derwin B., Grossberg L., O'Keefe B.J., Wartells E. eds. Rethinking Communication // Paradigm Exemplars. Sage Publications, 1989. - Vol 2. - P 397-410.

9 Ball-Rokeach S.J. and DeFleur M.L. A Dependency Model of Mass-Media Effects // Communication Research. - 1976. - Vol. 3(3). DOI: 10.1177/009365027600300101

10 McGuire W.J. The myth of massive media impact: Savagings and salvagings // Public Communication and Behavior. - 1986. - Vol. 1. - P. 173-257.

11 Mott F.L. Newspapers in presidential campaigns // Public Opinion Kuarterly. - 1944. - Vol. 8. - P. 348 -367.

12 Bryant J., Tompson S. Fundamentals of Media Effects McGraw-Hill Humanities/Social Sciences/Languages. 2001.

13 Seymour-Ure C. The political impact of mass media. - London and Beverly Hills, CA: Sage, 1974. 
14 Рубчевский К.В. СМИ и проблемы развития личности // Философия и общество. - 2006. - №1(42).

15 Kepplinger H.M. Media Effects: Direct and Indirect Effects // The International Encyclopedia of Communication. - 2008. doi:10.1002/9781405186407.wbiecm030

16 Festinger, L. (1957) A theory of cognitive dissonance. Stanford: Stanford University Press, 291 p. - book

17 Knobloch-Westerwick S. Choice and Preference in Media Use // Advances in Selective Exposure Theory and Research. - New York Routledge, 2014. - P. 496.

18 Potter W.J. Media Effects. - SAGE Publications Inc., 2012. - P. 377.

19 Singer J.L. The power and limitations of television: a cognitive-affective analysis. In P.H. Tannenbaum (Ed.) // The Entertainment Functions of Television. - Hillsdale, NJ: Erlbaum, 1978. - P.31-65.

20 Scheufele D.A. Framing as a Theory of Media Effects // Journal of Communication. - 1999. - Vol. 49. - P. 103-122.

21 Entman R.M. Framing U.S. Coverage of International News: Contrasts // Journal of Communication. - 1991. - Vol. 41, Issue 4. - P. 6-27.

22 Nickerson R.S. Confirmation bias: A ubiKuitous phenomenon in many guises // Review of General Psychology. - 1998. - 2(2). - P. 175-220.

23 Braun-LaTour K.A., LaTour M.S., Pickrell J.E., \& Loftus E.F. How and when advertising can influence memory for consumer experience // Journal of Advertising. - 2004. -№. 33(4). - P. 7-25.

24 Langer E.J., \& Piper A. Television from a mindful/mindless perspective // Applied Social Psychology Annual. 1988. - Vol. 8. - P. 247-260.

25 Eagly A.H., \& Chaiken S. Attitude structure and function. In D. T. Gilbert, S. T. Fiske, \& G. Lindzey (Eds.) // The Handbook of Social Psychology. - Oxford Univeristy Press, 1998. - P. 269-322

26 Goleman D. Emotional intelligence. - Bantam Books, Inc., 1995.

27 Lee S., \& Lang A. Discrete emotion and motivation: Relative activation in the appetitive and aversive motivational systems as a function of anger, sadness, fear, and joy during televised information campaigns // Media Psychology. - 2009. - Vol. 12. - P. 148-170. doi:10.1080/ 15213260902849927-

28 Mares M.-L. \& Oliver M.B. \& Cantor J. Age Differences in Adults' Emotional Motivations for Exposure to Films // Media Psychology. - 2008. - Vol. 11. - P. 488-511. 10.1080/15213260802492026. - internet

29 Holbert R. \& Hansen G. Fahrenheit 9-11, Need for Closure and the Priming of Affective Ambivalence: An Assessment of Intra-affective Structures by Party Identification // Human Communication Research. - 2006. - Vol. 32. - P. 109-129. 10.1111/j.1468-2958.2006.00005.x.

30 Tewksbury D. What Do Americans Really Want to Know? Tracking the Behavior of News Readers on the Internet // Journal of Communication. - 2003. - 53(4). - P. 694-710. doi:10.1111/j.1460-2466.2003.tb02918.x

31 Harrison K. \& Hefner V. Media, Body Image, and Eating Disorders. $n$ book: The Handbook of Children, Media, and Development. - 2009. - P. 381-406. 10.1002/9781444302752.ch17.

\title{
МРНТИ 19.01.11
}

https://doi.org/10.51889/2021-1.1728-7804.70

\author{
Sultanbayeva G., ${ }^{1}$ Lozhnikova $O .^{2}$ \\ ${ }^{1,2}$ Al-Farabi Kazakh National University, \\ Almaty, Kazakhstan
}

\section{DIGITAL TRANSFORMATION IN THE KAZAKHSTAN}

\section{Abstract}

This research presents the results of a sociological study on the media behavior of the adult population of Kazakhstan. The aim of the research is to identify the specifics of media consumption of digital technologies and media preferences of the adult population.

The main task of our empirical research is to determine the mechanism of access to the main technical means, and the media behavior of active users. The research methodology includes Kuantitative and Kualitative methods: a survey among the target group, sampling over 2500 respondents from all regions of Kazakhstan. We conclude that three Kuarters of the respondents will use three main channels: television, informal channels and Internet resources. Currently, there is a preserved tradition of formalized passive perception of information through television. The results of the study can be used in applied work in media marketing and digital business.

Keywords: digital media, digital transformation, media activity, media behaviour, media consumption

$$
\begin{gathered}
\text { Султанбаева Г., }{ }^{1} \text { Ложсникова } \text { O. }^{2} \\
{ }^{1,2} \text { Казахский национальный университет им. Аль-Фараби, } \\
\text { Алмать, Казахстан }
\end{gathered}
$$

